\title{
ANALISIS DANA TALANGAN HAJI PADA BANK MEGA SYARIAH CABANG PEKANBARU MENURUT HUKUM ISLAM
}

\author{
Ahmad Maulidizen \\ University of Malaya \\ ahmadzen682@gmail.com
}

Diterima 22 Januari 2018 | Direview 24 Maret 2018| Diterbitkan 01 Oktober 2018

\begin{abstract}
:
Syariah banking in Indonesia is experiencing significant developments, including assets, financial services, and the number of customers. Haj funds is a financial service using a contract of qard or ijarah given to prospective pilgrims in an effort to obtain the portion number of Hajj or Biaya Perjalanan Ibadah Haji (BPIH). The implementation of this product gives a positive and negative impression, so the legitimacy of the product and the consequences of its implementation need to be reviewed. This article will explain the implementation of the Hajj Fund of Bank Mega Syariah Branch Pekanbaru and revisit the Islamic Law on the implementation of these products. The purpose of this research is to facilitate the implementation of Haij Funds products as well as to get a legitimate status of product. The results of this study shows that the akad/contract itself has a great risk of hidden usury because in this contract there is a merger between akad qard and ijarah by requiring additional benefits as a service and the amount of the benefit depends on the amount and the length of loan. In fiqh muamalah, it is mentioned that that any profitable loan is riba.
\end{abstract}

Keywords: Haji funds, Bank Mega Syariah, Islamic Law

\begin{abstract}
Abstrak
Perbankan Syariah di Indonesia mengalami perkembangan signifikan, termasuk aset, pembiayaan yang diberikan dan jumlah pelanggan. Dana haji adalah pembiayaan dengan menggunakan kontrak qard atau ijarah yang diberikan kepada calon jemaah baji dalam upaya mendapatkan porsi jumlab Haji atau Biaya Perjalanan Ibadah Haji (BPIH). Penerapan produk ini memberi kesan positif dan negatif, sebingga perlu meninjau tentang legitimasi produk dan konsekuensi yang dihasilkan dalam pelaksanaannya. Karena artikel ini akan menjelaskan pelaksanaan Dana Haji Bank Mega Syariah Cabang Pekanbaru dan peninjauan kembali Hukum Islam tentang pelaksanaan produk tersebut. Tujuan penelitian ini agar pelaksanaan produk Dana Haji selain untuk
\end{abstract}


memudahkan pelanggan dalam melakukan ziarah, tetapi juga mendapatkan status legitimasi produk. Hasil dari penelitian ini adalah validitas akadnya yang sangat berisiko untuk terjerembab ke riba yang tersembunyi, karena dalam kontrak ini ada penggabungan antara akad qard dan ijarab dengan membutubkan manfaat tambahan sebagai layanan, babkan jumlahnya tergantung pada jumlah pinjaman dan panjang pinjaman. Dalam fiqh muamalah diketahui kaedah bahwa "Setiap piutang yang untung atau lebih adalab riba"

Kata kunci: Dana Haji, Bank Mega Syariah, Hukum Islam

\section{Pendahuluan}

Haji ${ }^{1}$ merupakan salah satu ibadah pokok dalam Islam, dan bagi setiap muslim yang sudah mampu wajib melaksanakanya satu kali seumur hidup. Dalam istilah syara' haji adalah bentuk peribadatan menuju ke Baitullah dan tempat-tempat tertentu untuk melaksan, akan amalan-amanalan ibadah tertentu, yang dimaksud dengan tempat-tempat tertentu, selain Ka'bah dan Mas'a (tempat sai), juga Arafah, Muzdalifah, dan Mina, dan yang dimaksud dengan waktu tertentu ialah bulan-bulan haji yang dimulai dari Syawal sampai 10 hari pertama bulan Dzulhijah. Adapun amal ibadah tertentu ialah thawaf, sa'i, wukuf, mabit di Muzdalifah, melontar jumrah, mabit di Mina, dan lain-lain. ${ }^{2}$ Sebagai ritual yang penuh simbol perjalan seorang hamba menuju Allah SWT, dalam pelaksanaan ibadah haji berimplikasi luas terhadap kehidupan masyarakat Muslim. Pelaksanaan ibadah haji bagi seorang Muslim Indonesia tidak hanya sebagai tuntutang rukun Islam yang kelima, ${ }^{3}$ tetapi sangat terkait

1 Secara lughawi, haji berarti menyengaja atau menuju dan mengunjungi. Menurut etimologi bahasa Arab, kata haji mempunyai arti qậād, yakni tujuan, maksud, dan menyengaja. Sayyīd Sābiq, Fiqh al-sunnah, Juz 8 (Kairo: Maktabah Dār al-Salām, 1998), h. 28.

2 'Abd al-Raḥmān al-Jazairi, al-Fiqh 'Alā Maz̧ahib al-Arba'ab, Juz IV (Meșir: Maktabah al-Tijāriyah, 1999), h. 44

${ }^{3}$ Ibadah Haji dalam al-Qur'an terdapat dalam Surah.Al-Baqarah [2]: 158, 189, 196-203, Ali Imrān [3]: 97, Al-Māidah [5]: 1-2, 97, dan al-Hajj. Penetapan Haji sebagai rukun Islam yang kelima diantaranya dirumuskan dari hadis Nabi SAW riwayat Bukhārī, Muslim, al-Turmudzī dan Abū Dāwūd bersumber dari 'Abd Allāh bin 'Umar. Demikian juga dalam hadis Jibril tentang Iman, Islam dan Ihsan. Lihat Abū 'Abd Allāh bin Ismā̄il al-Bukhārī, Șaḥiḥ al-Bukhārì, Juz 1 (Semarang: Maktabah Toha Putra, 2003), h. 11-12; Abū al-Ḥusain bin al-Ḥajjaj al-Qushairī al-Naisbūrī, Imām Muslim, Ṣahīh Muslim, Juz 1 (Beirut: Dār al-Fikr, 1992), h. 45; Abū Isā Muḥammad bin Isā alTurmudhī, Sunan al-Turmudhì, Juz 1 (Beirut: Dār al-Fikr, 1980), h. 38; Abū Dāwūd 
dengan berbagai aspek sosial. Banyak segi kehidupan bermasyarakat yang terlibat dalam penyelengaraan ibadah haji, mulai dari persepsi masyarakat terhadap makna haji, nilai, dan norma-norma yang terkandung di dalamnya, status orang yang telah berhaji, aspek ekonomi, hingga politik. ${ }^{4}$

Konsekuensi logis dari semua itu, maka penyelenggaraan ibadah haji menuntut campur tangan dan tanggung jawab pemerintah secara serius dari pemerintah Saudi Arabia sebagai tuan rumah maupun pemerintah Indonesia sebagai tamu. Tuntutan itu semakin mendesak manakala minat jamaah haji dari berbagai negara terus bertambah secara signifikan dan bahkan melampaui batas kuota yang ditetapkan pemerintah Saudi Arabia. Permasalahan yang timbul sekarang adalah banyaknya minat masyarakat untuk menunaikan ibadah haji dan terbatasnya daya tampung di tanah suci Mekkah sehingga membatasi bagi jamaah untuk melaksanakan ibadah haji setiap tahunya. Adanya porsi tunggu bagi jamaah, maka jamaah berlomba-lomba dalam mendaftarkan diri sebagai jamaah haji karena keterlambatan pendaftaran, mengakibatkan jamaah antri terlalu lama. Namun itu bagi jamaah yang telah cukup dana untuk mengambil porsi yang telah ditetapkan pemerintah, sedangkan bagi jamaah yang dananya belum cukup ini merupakan suatu kendala bagi jamaah untuk mendaftarkan dirinya sebagai calon jamaah haji. Oleh sebab itu banyak Instansi keuangan termasuk bank yang menawarkan jasa untuk mendaftarkan jamaah untuk mengambil nomor porsi haji atau Biaya Perjalanan Ibadah Haji (BPIH) yang disebut dengan dana talangan haji.

Sulaimān bin al-Asy’ats al-Sijistānī, Sunan Abū Dāwñ̀d, Juz 1 (Beirut: Dār al-Fikr, 1990), h. 95 .

${ }^{4}$ Jazuni, Legislasi Hukum Islam Di Indonesia (Jakarta :Citra Aditya Bhakti, 2005), h. 409. Dede Rosyada, Hukum Islam Dan Pranata Sosial (Jakarta : PT. Raja Grafindo Persada, 1999), h. 15. 


\section{Tabel 1 Jumlah Nasabah Dana Talangan Haji Bank Mega Syariah Cabang Pekanbaru Tahun 2010-2012}

\begin{tabular}{ccc}
\hline No & Tahun & Jumlah Nassabah \\
\hline 1 & 2010 & 21 \\
2 & 2011 & 624 \\
& & 207 \\
3 & 2012 & (Data sampai dengan bulan Fabruari) \\
\hline
\end{tabular}

Karena peningkatannya yang signifikan dan banyak diminati masyarakat merupakan indikasi bahwa produk dana talangan haji Bank Mega Syariah Cabang Pekanbaru ini memberikan dampak positif bagi masyarakat atau nasabah dan perbankan. Sebab, keberadaan dana talangan haji merupakan alternatif yang cukup menarik untuk mengatasi masalah sulitnya berhaji, baik karena faktor pendanaan yang belum mencukupi maupun karena terbatasnya kuota haji yang tersedia untuk calon jamaah haji di Indonesia, khususnya calon jamaah haji Pekanbaru. Namun demikian, disisi lain adanya produk dana talangan haji tersebut ada unsur riba dalam prakteknya. Hal ini disebabkan karena aplikasi dana talangan haji mengharuskan calon jamaah haji membayar sejumlah uang lebih dari dana yang dipinjamkan sebagai imbalan jasa (fee / ujrob) yang disinyalir sebagai riba dibalik praktik utang piutang dan pinjam meminjam, sebagaimana dalam tinjauan Hukum Islam dikenal kaedah fiqh muamalah bahwa:

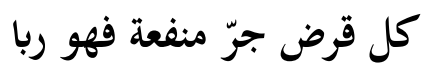

"Setiap piutang yang mendatangkan keuntungan atau lebih adalah riba". ${ }^{6}$

\footnotetext{
${ }^{5}$ Dokumentasi, Bank Mega Syariah Cabang Pekanbaru, 08 Maret 2012.

${ }^{6}$ Lihat Abū Isḥāq Ibrāhim al-Shirāzì (t.t), al-Mubadždžab, Juz 1 (Beirut : Dār al-Fikr), h. 304. Taqiyuddin 'Abd al-Abbas Aḥmad bin 'Abd al-Salām bin 'Abd Allāh bin Muhammad bin Taimiyah (t.t), al-Majmū' al-Fatāwsā, Juz 29 (Kairo: Maktabah Dār al-
} 
Dengan kata lain, di setiap piutang sebagaimana dana talangan haji yang dipersyaratkan akan mendatangkan manfaat bagi pemberi piutang adalah riba, dan seorang Muslim yang melakukan hal itu, ketika persyaratan mengambil keuntunganya terjadi pada saat akad berlangsung, maka akad hutang piutangnya dinilai tidak sah dan batal. ${ }^{7}$

Latar belakang di atas, tulisan ini akan memperbincangkan beberapa permasalahan dengan rumusan masalah sebagai berikut:

1. Bagaimana aplikasi dana talangan haji di Bank Mega Syariah Cabang Pekanbaru?

2. Bagaimana aplikasi dana talangan haji di Bank Mega Syariah Cabang Pekanbaru menurut Hukum Islam?

Dari rumusan masalah di atas, maka penulis berharap penelitian ini bertujuan untuk mengetahui aplikasi aplikasi dana talangan haji di Bank Mega Syariah Cabang Pekanbaru dan tinjauan Hukum Islam terhadap pelaksanaannya.

\section{Metode}

Penelitian ini termasuk dalam jenis penelitian lapangan (field research), dengan metode deskriptif analisis, yaitu suatu metode dalam meneliti status kelompok manusia, suatu objek, suatu kondisi, suatu system pemikiran atau suatu kelas peristiwa pada masa sekarang. Dilakukan di Bank Mega Syariah Cabang Pekanbaru. Populasi berjumlah 852 orang, diambil 85 orang (10\%) sebagai sampel penelitian, dengan menggunakan teknik random sampling. Teknik pengumpulan data; survey, angket dan wawancara.

Salām,tt), h. 533. Abū Yaḥyā Zakariyyā al-Anșārī (t.t), Fath al-Wabäb bi Sharh Manbāj al-Tulläb, Juz 1 (Beirut: Dār al-Fikr), h. 327.

${ }^{7}$ Lihat Muhammad Nawāwī bin 'Umar al-Jāwī, Nihāyah al-Zain fì Ishad al-Mutāilibin (Semarang: Toha Putra, 2000), h. 242; Imām Khāțib al-Sharbīnī, Mughnī al-Mubtäj, Juz 2 (Semarang: Toha Putra, 2000), h. 119; Imām Ramlī, Nihàyaàt al-Muhtäj, Juz IV (Semarang: Toha Putra, 2000), h. 231. 


\section{Pembahasan}

\section{Penyaluran Dana Talangan Haji Pada Bank Mega Syariah Cabang Pekanbaru}

\section{Produk Pembiayaan Dana Talangan Haji Pada Bank Mega Syariah Cabang Pekanbaru}

Produk pembiayaan dana talangan haji pada Bank Mega Syariah Cabang Pekanbaru adalah pinjaman dana talangan dari bank kepada nasabah khusus menutupi kekurangan dana untuk memperoleh kursi (seat) haji dan pada saat pelunasan Biaya Perjalanan Ibadah Haji (BPIH). Untuk membayar Biaya Perjalanan Ibadah Haji (BPIH), calon jamaah haji harus menyediakan uang atau modal sebesar Rp. 25.000.000,- untuk bisa mendapatkan nomor kursi keberangkatan haji. Tetapi tidak banyak masyarakat (calon jemaah haji) yang dapat membayar, karena masih terkendala dana yang belum terkumpul dalam waktu dekat. Oleh sebab itulah lembaga keuangan diberi kesempatan untuk membantu pengurusan haji. Dalam hal ini Bank Mega Syariah Cabang Pekanbaru menyediakan dana talangan bagi masyarakat (calon jamaah haji) yang masih kekurangan dana. Dengan adanya talangan tersebut dapat membantu mempercepat masyarakat mendapatkan kursi. ${ }^{8}$

Besarnya nominal Biaya Perjalanan Ibadah Haji (BPIH) sesuai ketentuan Kementerian Agama bahwa selama 5 tahun terakhir dan sampai dengan bulan April 2012, besarnya nominal Biaya Perjalanan Ibadah Haji (BPIH) adalah Rp. 25.000.000,0 adapun Biaya Perjalanan Ibadah Haji (BPIH) tersebut dapat dilihat pada table berikut;

8 Ana Handayani, Widodo dan Maulana, RO Haji/Pembiayaan Dana Talangan Haji (PDTH), Wawancara, Bank Mega Syariah Cabang Pekanbaru, Tanggal 15 Desember 2012. Penjelasan ini juga dibenarkan oleh Laode Lukman Hasimin (Kepala Cabang) dan Pitria Liza (Kepala Operasional), Wawancara, Bank Mega Syariah Cabang Pekanbaru 
Tabel 2 Jumlah Pembiayaan Biaya Perjalanan Ibadah Haji (BPIH) 2008-20129

\begin{tabular}{ccc}
\hline No & Tahun & Biaya Perjalanan Ibadah Haji (BPIH) \\
\hline 1 & 2008 & Rp. 20.000.000,- \\
2 & 2009 & Rp. $20.000 .000,-$ \\
3 & 2010 & Rp. 20.000.000,- \\
4 & 2011 & Rp. 20.000.000,- \\
5 & 2012 & Rp. 25.000.000,- \\
\hline
\end{tabular}

Bagi nasabah dana talangan haji, sebelumnya harus mempunyai atau membuka rekening "Tabungan Haji". Tabungan Haji merupakan jenis produk pendanaan bank, melalui tabungan haji nasabah bisa mendapatkan dana talangan haji Bank Mega Syariah Pekanbaru. Tabungan Haji merupakan simpanan dalam mata uang rupiah yang bertujuan membantu masyarakat muslim dalam merencanakan ibadah haji dan umrah. Tabungan ini dikelola berdasarkan prinsip mudärabah mutlaqah, penyetoran awal terbilang Rp. 500.000. Tabungan Haji dilakukan nasabah yang ingin menabung untuk tujuan pembayaran Biaya Perjalanan Ibadah Haji (BPIH), tetapi waktu nasabah bisa mendapatkan porsi haji tergantung dengan kemampuannya dalam menabung. Lain halnya dengan dana talangan haji yang sudah jelas nasabah dengan waktu cepat mendapat porsi haji. ${ }^{10}$

Batas pembayaran maksimal 1 tahun setelah pengajuan pembiayaan. Selama masa pembayaran, nasabah boleh mencicil atau langsung tunai, karena bank akan mengambil secara sekaligus pada saat

9 Dokumentasi, Bank Mega Syariah Cabang Pekanbaru. Jl. Jenderal Sudirman No. 351 Pekanbaru, 2012. Produk dana talangan haji merupakan produk pembiayaan, produk ini diluncurkan oleh Bank Mega Syariah Cabang Pekanbaru sejak Juli 2010. Hal ini karena banyaknya permintaan dari nasabah yang menginginkan talangan untuk biaya haji. Mereka ingin mendapatkan porsi haji dengan cepat, sehingga keberangkatan ibadah haji bisa terencana melihat banyaknya daftar tunggu. Dengan talangan yang diberikan Bank Mega Syariah Cabang Pekanbaru mereka bisa mendapatkan porsi atau seat haji dengan pasti dan cepat sehingga perjalanan haji bisa terencana. Laode Lukman Hasimin, Kepala Cabang dan Pitria Liza, Kepala Operasional, Wawancara, Bank Mega Syariah Cabang Pekanbaru, 22 Desember 2012.

10 Ana Handayani, Widodo dan Maulana, RO Haji/PDTH, Wawancara, Bank Mega Syariah Cabang Pekanbaru, Tanggal 15 Desember 2012; Ibid 
akhir batas pembayaran melalui Tabungan Haji. Apabila nasabah tidak mampu membayar dari waktu yang sudah ditentukan, maka diberikan perpanjangan waktu untuk 1 tahun ke depan sampai sebelum keberangkatan ibadah haji dengan membayar biaya administrasi satu tahu mendatang. ${ }^{11}$ Dalam pembiayaan ini bank bertindak sebagai penyalur yang membantu pengurusan pendaftaran haji. Selanjutnya untuk daftar sebagai calon jamaah haji adalah tanggung jawab penuh nasabah. Nasabah (calon jamaah haji) memberikan kuasa pada bank untuk mengurusi semua yang menjadi persyaratan untuk mendapatkan porsi. Setelah berkas-berkas dan kekurangan Biaya Perjalanan Ibadah Haji (BPIH) untuk mendapatkan posri sudah terpenuhi, maka nasabah bisa langsung daftar ke Kementerian Agama. ${ }^{12}$

\section{Prosedur Permohonan Dan Syarat Pembiayaan Dana Talangan Haji Pada Bank Mega Syariah Cabang Pekanbaru}

Untuk pengajuan talangan haji pada Bank Mega Syariah Cabang Pekanbaru nasabah harus melalui beberapa tahapan. Diantaranya; ${ }^{13}$

a. Tahap ke-1, Bank Mega Syariah Cabang Pekanbaru menerima permohonan pembiayaan dana talangan haji dari nasabah;

b. Tahap ke-2, bagian marketing menganalisa dengan mengacu pada Pedoman Pembiayaan Bank Mega Syariah Cabang Pekanbaru;

c. Tahap ke-3, pembukaan rekening Tabungan Haji Bank Mega Syariah Cabang Pekanbaru;

d. Tahap ke-4, meminta nasabah memenuhi saldo minimal Tabungan Haji Bank Mega Syariah Cabang Pekanbaru, self financing biaya pendaftaran haji sebagai dasar pengajuan talangan pendaftaran haji dan biaya-biaya yang dikenakan kepada nasabah;

e. Tahap ke-5, bagian marketing menyerahkan data calon jamaah haji kepada kepala cabang. Pada tahap ini data-data yang telah dianalisa oleh marketing diajukan kepada kepala cabang untuk mendapatkan persetujuan;

11 Ibid

12 Laode Lukman Hasimin, Kepala Cabang dan Pitria Liza, Kepala Operasional, Wawancara, Bank Mega Syariah Cabang Pekanbaru, 22 Desember 2012

13 Ana Handayani, Widodo dan Maulana, RO Haji/PDTH, Wawancara, Bank Mega Syariah Cabang Pekanbaru, Tanggal 15 Desember 2012. 
f. Tahap ke-6, bagian marketing membuat SP3, memo, dan akad setelah mendapat persetujuan, membuat surat permohonan pengajuan pembiayaan, memo dan akad, akan diserahkan kepada calon jamaah haji yang mengajukan talangan;

g. Tahap ke-7, bagian administrasi pembiayaan mengecek kelengkapan data calon jamaah haji;

h. Tahap ke-8, bagian administrasi pembiayaan menyerahkan data kepada Manager Operasional dan Kepala Cabang untuk dianalisa kembali dan mendapatkan persetujuan Kantor Cabang melakukan penandatanganan akad.

i. Tahap ke-9, bagian administrasi melakukan pencairan dana langsung ke rekening calon jamaah haji serta menginput Surat Pendaftaran Pergi Haji (SPPH) untuk mendapatkan porsi.

j. Tahap ke-10, MO melakukan monitoring pada dana talangan yang diajukan.

Sebelum melakukan permohonan dana talangan haji Bank Mega Syariah Cabang Pekanbaru, ada beberapa syarat yang harus dipenuhi oleh pemohon, ${ }^{14}$ mencakup; 1) Syarat Pemohon, pemohon pembiayaan dibatasi hanya nasabah yang telah memiliki Tabungan Haji Bank Mega Syariah Cabang Pekanbaru dan menyetorkan BPIH melalui bank dengan kiteria; (a) cakap hukum; (b) perorangan yang mempunyai pekerjaan tetap dan/atau yang menurut penilaian bank diyakini memiliki kemampuan mengembalikan dana talangan haji tepat pada waktunya, dan (c) bersedia memberikan jaminan sesuai ketentuan bank. Nisbah memberikan jaminan kepada bank sesuai surat akad. ${ }^{15}$ 2) Syarat Nasabah atau Pemohon Dana Talangan Haji, adapun syarat pemohon meliputi; Nasabah perorangan, melengkapi; (a) Fotokopi KTP pemohon; (b) Fotokopi KTP suami/istri pemohon (apabila telah menikah); (c) Fotokopi Kartu Keluarga dan Surat Nikah (bila sudah menikah). Surat Cerai (bila janda/duda), (d) Surat Pernyataan batal haji; (e) Surat permohonan pengunduran diri dari calon jamaah kepada Kantor Kementerian Agama setempat; (f) Surat kuasa pengurusan pembatalan haji; (g) menyediakan kekurangan dana pendaftaran haji yang menjadi

14 Laode Lukman Hasimin, Kepala Cabang dan Pitria Liza, Kepala Operasional, Wawancara, Bank Mega Syariah Cabang Pekanbaru, 22 Desember 2012

15 Dokumentasi, Bank Mega Syariah Cabang Pekanbaru. Jl. Jenderal Sudirman No. 351 Pekanbaru, 2012. 
beban nasabah pada rekening Tabungan Haji Bank Mega Syariah Cabang Pekanbaru atas nama nasabah/ calon jamaah haji; (h) Fotokopi Tabungan Haji Bank Mega Syariah Cabang Pekanbaru. ${ }^{16}$

Sementara syarat kelompok Bimbingan Ibadah Haji (KBIH)/ Penyelenggara Ibadah Haji Khusus (PIHK), melengkapi; (a) Fotokopi Akta Pendirian/ Anggaran Dasar; (b) Fotokopi KTP pengurus/ pihak yang berwenang mengajukan permohonan pembiayaan sebagaimana diatur dalam Akte Pendirian/ Anggaran Dasar; (c) Fotokopi Surat Izin Operasional dari Departemen Agama; (d) NPWP (untuk pembiayaan limit di atas Rp. 50.000.000,-; (e) Daftar nama calon haji yang akan diajukan untuk memperoleh talangan pendaftaran haji; (f) menyediakan kekurangan dana pendaftaran haji yang menjadi beban seluruh calon haji di bawah tanggung jawab Kelompok Bimbingan Ibadah Haji $(\mathrm{KBIH})$ dimaksud pada rekening Tabungan Haji Bank Mega Syariah Cabang Pekanbaru atas nama masing-masing calon haji yang diblokir oleh bank; (g) Fotokopi KTP calon jamaa haji yang akan diajukan untuk memperoleh talangan pendaftaran haji; (h) Fotokopi Tabungan Haji Bank Mega Syariah Cabang Pekanbaru calon jamaah haji yang akan diajukan untuk memperoleh dana talangan haji. Untuk permohonan pembiayaan dana talangan haji yang akan diajukan oleh Kelompok Bimbingan Ibadah Haji (KBIH)/ Penyelenggara Ibadah Haji Khusus (PIHK), selain surat permohonan dana talangan haji dari Kelompok Bimbingan Ibadah Haji (KBIH)/ Penyelenggara Ibadah Haji Khusus (PIHK), juga wajib dilampiri permohonan pembiayaan dan sudah menandatangani dokumen-dokumen yang melalui Kelompok Bimbingan Ibadah Haji (KBIH)/ Penyelenggara Ibadah Haji Khusus (PIHK). ${ }^{17}$

Sebagai lembaga keuangan yang berusaha meningkatkan kualitas pelayanan tanpa merugikan kedua belah pihak antara bank dan nasabah, terlebih dahuu dipertimbangkan sebelum memberikan pembiayaan pada nasabah, dengan menggunakan 6 C'S, yaitu; (1) Character; Pembiayaan dana talangan haji Bank Mega Syariah Cabang Pekanbaru dikendalikan oleh bagian RO Haji/ Pembiayaan Dana Talangan Haji, mereka yang bertanggung jawab untuk memberikan permohonan dana talangan atas nasabah. Setelah pembiayaan ini ditangani oleh Customer Service, dari pihak marketing menganalisa data nasabah terkait dengan kehidupan

16 Ibid.

17 Ibid 
pribadi atau latar belakang nasabah. Upaya-upaya yang menggambarkan nasabah, diantaranya; (a) meneliti riwayat calon nasabah; Dalam hal ini bagian marketing mempelajari riwayat hidup dari nasabah, karena sebelumnya pihak bank sudah memberikan formulir untuk pengajuan dana talangan haji, yang sudah diisi oleh nasabah terkait dengan keadaan nasabah mulai dari nama, alamat, status nasabah, pekerjaan, jabatan dll; (2) Cakap Hukum; Nasabah harus mengerti tetang hokum dalam hal ini nasabah minial harus mengerti tentang perkreditan yang akan dia lakukan; (3) Melakukan Wawancara; Dalam hal ini pihak Customer Service memperhatikan nilai-nilai yang ada pada nasabah, misalnya; tata cara nasabah berpenampilan, bertutur kata, serta menunjukkan keyakinan untuk melakukan pembayaran. Bagian Marketing/ AO bertugas menganalisa pekerjaan dari nasabah; (4) Capital/ Modal; Bank harus mengetahui berapa jumlah modal atau dana yang bisa disediakan sendiri oleh nasabah. Dalam praktiknya; bank mengalisa kekayaan dari nasabah, bank bertugas dengan melihat slip gaji dari nasabah, dan aset yang bisa meyakinkan nasabah dalam membayar utang, aset ini bentuknya tidak harus berupa uang, tanah atau bisa dalam bentuk bangunan. Modal awal yang harus disediakan bagi nasabah dalam permohonan bermacammacam, di antaranya; 10 juta, 15 juta dan 18 juta. Persyaratan ini bertujuan untuk memberikan kemudahan untuk memilih dana sesuai dengan kemampuan nasabah; (5) Capacity/ Kemampuan; Analisa ini bertujuan untuk mengetahui kemampuan yang dimiliki nasabah dari segi pendapatan. Upaya-upaya untuk bisa mengetahui kemampuan nasabah baik dari perorangan maupun $\mathrm{KBIH}$, melalui beberapa pendekatan, diantaranya; (a) Bank Mega Syariah Cabang Pekanbaru melakukan pendekatan dari segi financial, yaitu; menilai latar belakang nasabah dari segi keuangan dan apabila permohonan dari KBIH pihak bank menilai keadaan dari yayasan penyelenggara ibadah haji tersebut; (b) Pendekatan Yuridis, yaitu permohonan dari KBIH apakah Yayasan tersebut mempunyai kapasitas untuk mewakili lembaga untuk mengadakan perjanjian pembiayaan dana talangan haji Bank Mega Syariah Cabang Pekanbaru; (c) Manajerial, yaitu menilai kemampuan nasabah (perorangan/ Kelompok Bimbingan Ibadah Haji) mulai dari perencanaan awal sampai pencairan dana talangan; (6) Collateral; Bank Mega Syariah Cabang Pekanbaru, memberikan kewajiban bagi nasabah untuk dapat memberikan jaminan. Jenis dari agunan ini dari pihak Bank 
Mega Syariah Cabang Pekanbaru meminta nasabah untuk memberikan "Surat Pernyataan Pembatalan Keberangkatan Haji di atas materai". Dapat mempengaruhi kelancaran pembiayaan. Upaaya-upaya untuk mengantisipasi terjadinya risiko, diantaranya; (a) Pemasaran; permintaan untuk talangan haji, persaingan antar bank, keadaan pasar, keadaan nasabah terutama wilayah Kota Pekanbaru; (b) Teknik dalam menarik nasabah dengan berbagai fasilitas yang disediakan, misalnya memberikan 3 pilihan dana talangan, perpanjangan waktu. Adapun waktu untuk keberangkatannya adalah tergantung kuota yang berada di daerah masing-masing; (c) Peraturan Pemerintah; Dalam hal ini jenis pembiayaan ini sudah mendapatkan fatwa dari MUI, dengan menggunakan akad qand dan bisa juga menggunakan akad ijärab; (7) Contrains; Dalam hal ini Bank Mega Syariah Cabang Pekanbaru tidak akan memberikan talangan haji bagi nasabah yang kurang mampu dari segi modal, dan kurang meyakinkan untuk melakukan pembayaran. Untuk Kelompok Bimbingan Ibadah Haji (KBIH), yayasan tidak mempunyai nilailebih atau unggul di dalam pengurusan ibadah haji, yang memungkinkan pembiayaan mereka akan ditolak Bank Mega Syariah Cabang Pekanbaru. Dari keenam prinsip di atas yang paling perlu mendapatkan perhatian bagian RO Haji/ PDTH adalah character, apabila prinsip ini tidak terpenuhi, maka prinsip lainnya tidak berarti, atau dengan kata lain, permohonannya harus ditolak.

\section{Akad penyaluran Dana Talangan Haji Pada Bank Mega Syariah Cabang Pekanbaru}

Dalam melaksanakan program pembiayaan Dana Talangan Haji Bank Mega Syariah Cabang Pekanbaru menggunakan dua prinsip, yaitu sewa (ijärah) dan pelengkap (Qard). Ijärah, bank bertugas sebagai pihak yang memberikan jasa sewa (memberikan talangan) dengan mengambil upah jasa (fee/ujroh) dari biaya-biaya administrasi yang dilakukan oleh bank karena sudah membantu nasabah dalam memperoleh porsi atau kursi keberangkatan haji. Qard, disini pihak bank bertugas memberikan pinjaman kepada nasabah. ${ }^{18}$ Dalam praktik akad Qard, bank tidak mengambil keuntungan sesuai dengan prinsip Syariah, bank hanya

\footnotetext{
18 Ana Handayani, Widodo dan Maulana, RO Haji/PDTH, Wawancara, Bank Mega Syariah Cabang Pekanbaru, Tanggal 15 Desember 2012.
} 
bertindak sebagai pemberi pinjaman dan nasabah hanya wajib mengembalikan pokok utang pada waktu tertentu yang telaah disepakati di masa yang akan dating. Keuntungan diperoleh dari praktik akad ijärah, yaitu dengan mengambil upah jasa dari biaya administrasi atau lebih dikenal dengan (fee/ujrah) dari setiap dana disediakan oleh bank. Biaya administrasi itu terbagi menjadi empat kategori, yaitu; (1) Biaya administrasi Rp. 500.000,- dan (2) Talangan Rp. 12.500.000,- fee ijärah yang harus dibayar Rp.2.500.000,-; (3) Talangan Rp. 15.000.000,- fee ijärah yang harus dibayar Rp. 2.500.000,- (4) Talangan Rp. 20.000.000 fee ijärah yang harus dibayar Rp. $2.500 .000,-\cdot{ }^{19}$

Berdasarkan uraian tersebut, bahwa tidak banyak nasabah yang dapat membayar BPIH dari jumlah yang ditentukan Kementerian Agama, kendala mereka bisa pada dana yang masih belum smua terkumpul dalam waktu dekat, kekurangan dana tersebut berbeda-beda, oleh karena itu Bank Mega Syariah Cabang Pekanbaru menyediakan beberapa pilihan jumlah nominal bagi para nasabah yang ingin menggunakan jasa talangan haji Bank Mega Syariah Cabang Pekanbaru. Adapun fasilitas pembiayaan dana talangan haji Bank Mega Syariah Cabang Pekanbaru;

1) Pinjaman dalam bentuk rupiah;

2) Jangka waktu maksimum pembayaran 12 bulan atau 1 tahun dan pembayaran dapat diangsur setiap bulan atau sekaligus sebelum jatuh tempo

3) Nominal talangan haji dan fee ujrah yang harus dibayar

4) Jumlah nominal yang disediakan bagi nasabah menggunakan jasa talangan haji Bank Mega Syariah Cabang Pekanbaru adalah; (a) biaya administrasi Rp. 500.000,- dan (b) Talangan Rp. 12.500.000,- fee ijärah yang harus dibayar Rp.2.500.000,-; (c) Talangan Rp. 15.000.000,- fee ijärah yang harus dibayar Rp. 2.500.000,- (d) Talangan Rp. 20.000 .000 fee ijärah yang harus dibayar Rp. 2.500.000, ${ }^{20}$ 


\section{Gambar 1 Dana Talangan Haji Bank Mega Syariah Cabang Pekanbaru}

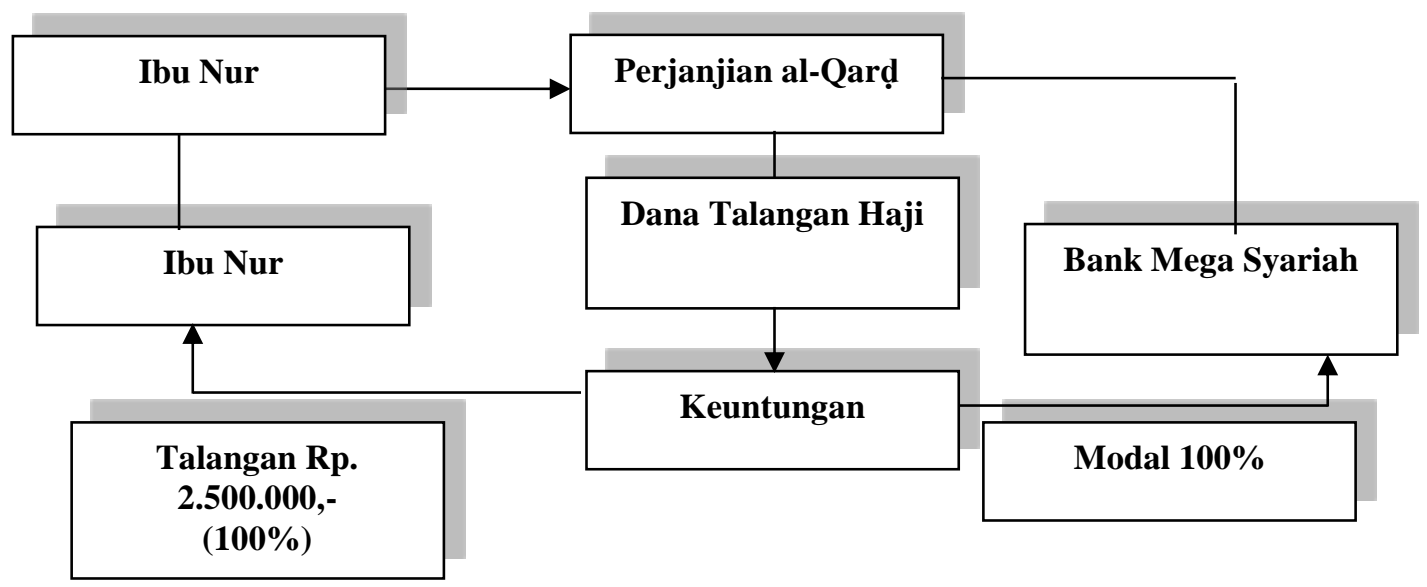

Berdasarkan gambar di atas menunjukkan bahwa pinjaman (keuntungan) yang diperoleh oleh ibu Nur Rp. 12.5000.000,- sedangkan Bank Mega Syariah Cabang Pekanbaru kembaali modal (pengembalian dana bank) Rp. 12.500.000,pengembaliannya sesuai pokok pinjaman tanpa bank harus mengambil keuntungan. Selanjutnya upah jasa dibebankan pada penggunaan akad ijärah. Dengan akad ijärah Bank Mega Syariah Cabang Pekanbaru bertugas sebagai pihak yang memberikan jasa sewa (memberikan talangan). Bank mengambil upah jasa dengan jumlah yang sama, dan nasabah hanya membayar upah jasa sesuai dengan jumlah yang telah ditetapkan oleh bank dan sesuai dengan kesepakatan pada saat akad dana talangan, baik dalam bentuk qirad maupun jjärah. Tindakan ini dilakukan untuk memberikan kemudahan bagi nasabah. Sebagai contoh berikut;

\section{Contoh A}

Permohonan pembiayaan

Pemohon

Alamat

Pekanbaru

Perihal

Dana Talangan

Tanggal Pengajuan

Batas Pembayaran: 04 April 2012
: Ibu Nur

: Jl. KH. Ahmad Dahlan No. 7 Sukajadi

: Permohonan Dana Talangan Haji

: Rp. 12.500.000,-

: 03 Mei 2011 
Biaya-biaya

$\begin{array}{ll}\text { Modal } & \text { : Rp. } 12.500 .000,- \\ \text { Fee Ujrah } & \text { : Rp. } 2.500 .000,- \\ \text { Tabungan Haji } & \text { : Rp. } 500.000,- \\ \text { Total Biaya } & \text { : Rp. } 15.500 .000,-\end{array}$

\section{Contoh B}

Permohonan pembiayaan

Pemohon

Alamat

Perihal

Dana Talangan

Tanggal Pengajuan
: Bapak Jufri

: Jl. Melur No. 19 Padang Bulan Pekanbaru

: Permohonan Dana Talangan Haji

: Rp. 15.000.000,: 08 Agustus 2011

Batas Pembayaran: 06 Juli 2012

Biaya-biaya

Modal

Fee Ujrah

Tabungan Haji

Total Biaya

:Rp. 10.000.000,-

:Rp. 2.500.000,-

:Rp. 500.000,-

:Rp. 13.000.000,-

\section{Contoh C}

Permohonan pembiayaan

Pemohon

Alamat

Pekanbaru

Perihal

Dana Talangan

Tanggal Pengajuan

Batas Pembayaran: 06 Juli 2012
: Bapak Lukman

: Jl. Markisa No. 19 Marpoyan Damai

: Permohonan Dana Talangan Haji

: Rp. 20.000.000,-

: 08 Agustus 2011

Biaya-biaya

Modal

: Rp. 5.000.000,-

Fee Ujrah

:Rp. 2.500.000,-

Tabungan Haji

:Rp. 500.000,-

Total Biaya

: Rp. 8.000.000,-

Berdasarkan penjelasan sebelumnya, Bank Mega Syariah Cabang Pekanbaru membebankan upah jasa tidak ditentukan pada dana talangan yang 
diajukan. Dari ketiga contoh di atas, tidak ada perbedaan upah jasa yang harus ditanggung oleh pemohon. Upah jasa yang dibayarkan Ibu Nur lebih murah dibandingkan upaah jasa yang harus dibayar Pak Jufri dan Pak Lumkan, hal ini terjadi karena modal yang dimiliki lebih sedikit. Sehingga permohonan pembiayaan atau kekurangan dananya lebih besar dibandingkan dengan Ibu Nur. Dari ketiga permohonan di atas modal Pak Jufri yang paling sedikit dibandingkan dengan Pak Luman. Kondisi inilah yang membuat Pak Jufri menanggung upah jasa lebih besar.

Berdasarkan Fatwa Dewan Syariah Nasional No. 29/DSNMUI/VI/2002, tentang pembiayaan pengurusan haji kepada nasabah, lembaga keuangan Syariah dapat memperoleh imbalan atau ujrah dengan menggunakan prinsip ijärah sesuai Fatwa Dewan Syariah Nasional No. 9/DSNMUI.IV/2000. Sedangkan untuk pengambilan ujrah memutuskan bahwa, "Besar imbalan jasa ijärah tidak boleh didasarkan pada jumlah talangan al-Qard yang diberikan lembaga keuangan Syariah kepada nasabah. ${ }^{21}$ Pengambilan upah tersebut sebagai ganti biaya-biaya administrasi yang dikeluarkan bank, jadi meskipun jumlah talangan berbeda proses administrasi dari pemohon tersebut sama. Akan tetapi Bank Mega Syariah Cabang Pekanbaru juga memperhitungkan dengan melihat risiko pembiayaan yang diberikan pada nasabah semakin besar dana talangan, maka risiko bank semakin besar. Hal ini menunjukkan risiko pembiayaan Pak Jufri dan Pak Lumkan lebih besar daripada Ibu Nur.

\section{Tinjauan Hukum Islam Terhadap Dampak Dana Talangan Haji Pada Bank Mega Syariah Cabang Pekanbaru}

Produk dana talangan haji Bank Mega Syariah Cabang Pekanbaru memiliki sisi positif (manfaat) dan negatif (mafsadah). Sisi positif dari produk dana talangan haji dapat memberikan manfaat ganda; manfaat bagi nasabah dan bani bank. Manfaat yang dirasakan oleh nasabah antara lain; (1) nasabah dijamin bisa mendapatkan kursi haji dengan cepat, meskipun dari dana mereka tidak tidak mencukupi pembayaran biaya perjalanan haji, sehingga dapat daftar sebagai calon jamaah haji pada Kementerian Agama; (2) mencairkan dana secara mendesak bagi nasabah yang dananya masih belum bisa dicairkan dalam waktu cepat meskipun masih dalam bentuk deposito; (3) proses pemberian dana talangan haji relative cepat, sehingga keberangkatan ibadah haji dapat

21 Majelis Ulama Indonesia, Fatwa DSN-MUI No. 9/DSN-MUI/IV/2000 Jakarta: MUI, 2000) 
terencana dan tidak menunggu lama; (4) fee atau ujrah (uang administrasi) yang diberikan relatif murah; (5) nasabah hanya membayar produk dari pinjaman, bukan hanya kemudahan ini yang diberikan Bank Mega Syariah Cabang Pekanbaru; (6) nasabah dapat mengansur setiap bulan atau bisa juga dibayar langsung atau sekaligus sampai akhir pembayaran. ${ }^{22}$ Sementara manfaat yang dirasakan oleh bank, yaitu produk ini memiliki peminat yang cukup banyak sehingga berpotensi memajukan Lembaga Keuangan Syariah sebagai instrument ekonomi umat Islam.

Namun demikian, di sisi negatif dari pembiayaan dana talangan haji Bank Mega Syariah Cabang Pekanbaru, ia bisa saja dianggap sebagai bagian dari fath al-dzari'ah (membuka pintu bahaya) dan mendatangkan bahaya (mafsadah/ mudarat). Ditinjau dari Hukum Islam, keabsahan akadnya yang sangat riskan menjatuhkan kepada riba tersembunyi, karena dalam akad ini terjadi penggabungan antara akad al-qard dan al-jjärah dengan mensyaratkan adanya tambahan imbalan sebagai jasa, bahkan tambahan tersebut besarnya tergantung pada jumlah pinjaman dan lamanya masa pinjaman. Terdapat beberapa item dalam Surat Pernyataan dan Kuasa nasabah kepada bank; (1) untuk mendebet semua uang yang ada di rekening nasabah di bank, guna melunasi jumlah pokok pembiayaan, kewajiban dan/ atau biaya-biaya lain yang timbul sehubungan dengan fasilitas yang diterima nasabah dari bank; (2) untuk mengambil dan menggunakan jaminan yang diberikan oleh nasabah sehubungan dengan fasilitas yang diberikan oleh bank, jika karena suatu sebab nasabah dinyatakan Wan prestasi oleh bank. ${ }^{23}$

Beberapa item lainnya, dapat dilihat dalam Akad al-Qand pembiayaan dana talangan haji Bank Mega Syariah Cabang Pekanbaru, ialah Pasal 4; Biaya, Potongan dan Pajak; Nasabah berjanji dan dengan ini mengikatkan diri untuk menanggung segala biaya yang diperlukan berkenaan pelaksanaan akad ini termasuk Jasa Notaris dan jasa lainnya, sepanjang hal ini diberitahukan oleh bank kepada nasabah sebelum ditanda tangani akad ini, nasabah menyatakan persetujuannya; Pasal 6; Cedera Janji; Menyimpang dari ketentuan Pasal 2 Akad ini, bank berhak menuntut atau menagih pembayaran dari nasabah atau siapapun juga yang memperoleh hak darinya, atau sebagian atau seluruh jumlah

22 Ana Handayani, Widodo dan Maulana, RO Haji/PDTH, Wawancara, Bank Mega Syariah Cabang Pekanbaru, Tanggal 15 Desember 2012.

${ }_{23}$ Sumber Data, Dokumentasi, Surat Pernyataan dan Kuasa dalam Akad al-Qard Pembiayaan Dana Talangan Haji Bank Mega Syariah Cabang Pekanbaru, Pekanbaru, 2012. 
hutang nasabah kepada bank berdasarkan akad ini, untuk dibayar seketika atau sekaligus tanpa diperlukan adanya surat pemberitahuan, surat teguran atau surat lainnya, apabila terjadi salah satu dari peristiwa di bawah ini: (1) nasabah tidak melaksanakan kewajiban pembayaran/pelunasan tepat pada waktu yang telah diperjanjikan sesuai dengan tanggal jatuh tempo angsuran dan karenanya nasabah akan dikenakan denda administrasi keterlambatan sebagaimana diatur dalam Pasal 2 Ayat 4 Akad ini. ${ }^{24}$

Adanya tembahan imbalan sebagai jasa dan biaya-biaya lainnya dalam pembiayaan dana talangan haji Bank Mega Syariah Cabang Pekanbaru kepada nasabah, dalam hukum Islam termasuk kategori riba dan haram. Setiap qard (pinjaman) yang mensyaratkan tambahan termasuk riba, meskipun besarnya tak didasarkan pada jumlah dana yang dipinjamkan. Dalam fiqh muamalah dikenal kaedah bahwa "Setiap piutang yang mendatangkan keuntungan atau lebih adalah riba" 25 Jenis riba dalam konteks ini dalam kajian hukum Islam dikenal dengan istilah ribā al-Nasīah, atau disebut ribā duyun, yaitu riba yang timbul akibat utang piutang yang tidak memenuhi criteria untung muncul bersama risiko dan hasil usaha muncul bersama biaya. Transaksi semacam ini karena mengandung pertukaran kewajiban menanggung beban hanya karena berjalannya waktu. ${ }^{26}$ Tinjauan hukum Islam tentang riba didasarkan kepada firman Allah SWT;

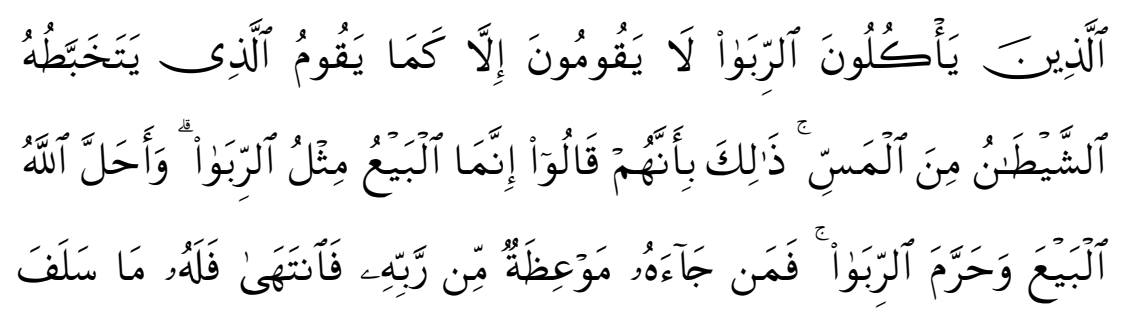

24 Ibid

${ }^{25}$ Abū Isḥāq Ibrāhim al-Shirāzī (t.t), al-Muhadżdzab,Juz 1 (Beirut : Dar al-Fikr), h. 304. Taqiyuddin Abd al-Abbas Ahmad bin 'Abd al-Salām bin 'Abd Allāh bin Muḥammad bin Taimiyah (t.t), al-Majmū' al-Fatāwā, Juz 29 (Kairo: Maktabah Dār al-Salām), h. 533. Abū Yaḥyā Zakariyyā al-Anșārī (t.t), Fath al-Wahāb bi Sharh Manhāj al-Tullāb,Juz 1 (Beirut : Dār al-Fikr), h. 327.

${ }^{26}$ Heri Sudarsono, Op.Cit, h. 6; Sulaimān Rashīd, Fiqh Islām (Jakarta: Pelajar, 2009), h. 290 


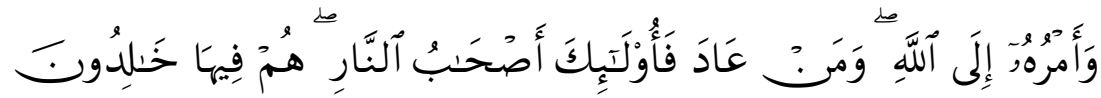

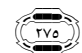

"Orang-orang yang Makan (mengambil) riba tidak dapat berdiri melainkan seperti berdirinya orang yang kemasukan syaitan lantaran (tekanan) penyakit gila. Keadaan mereka yang demikian itu, adalah disebabkan mereka berkata (berpendapat), Sesungguhnya jual beli itu sama dengan riba, Padahal Allah telah menghalalkan jual beli dan mengharamkan riba. orang-orang yang telah sampai kepadanya larangan dari Tuhannya, lalu terus berhenti (dari mengambil riba), Maka baginya apa yang telah diambilnya dahulu (sebelum datang larangan); dan urusannya (terserah) kepada Allah. orang yang kembali (mengambil riba), Maka orang itu adalah penghuni-penghuni neraka; mereka kekal di dalamnya. (al-Baqarah [2]: 275)
\end{abstract}

Sejalan dengan ayat di atas, dalam hadis riwayat imām Aḥmad yang bersumber dari 'Abd Allāh bin Mas'ūd, Rasulullah Saw bersabda; Satu Dirham dari hasil riba yang dimakan oleh seseorang dan ia mengetahuinya, niscaya dosanya lebih berat daripada dosa 36 kali berbuat zina (HR. A ḥmad); ${ }^{27}$ Jabir r.a berkata: "Rasulullah Saw, telah melaknati pemakan riba, orang yang memberikan/ membayar riba, penulisnya dan juga dua orang saksinya". Beliau juga bersabda, "Mereka itu sama dalam hal dosanya". ${ }^{28}$ Dengan kata lain, di setiap piutang sebagaimana dana talangan haji yang dipersyaratkan akan mendatangkan manfaat bagi pemberi piutang adalah riba, dan seorang Muslim yang melakukan hal itu, ketika persyaratan mengambil keuntungannya terjadi pada saat akad berlangsung, maka akad hutang piutangnya dinilai tidak sah dan batal. $^{29}$

${ }^{27}$ Imām Abū 'Abd Allāh Ibn Ḥanbal (t.t), Juz 2, Musnad Imām Aḥmad (Beirut: Dār alFikr), h 123

28 2; Abū al-Husain bin al-Hajjaj al-Qushairī al-Naisbūrī, Imām Muslim, Ṣahīh Muslim, Juz V (Semarang: Toha Putra, 2003), h. 50; Juz 3, h. 36

29 Muḥammad Nawāwī bin 'Umar al-Jāwī, Op.Cit, h. 242; Imām Khāṭib al-Sharbīnī, Op.Cit, h. 119; Imām Ramlī, Op.Cit, h. 231. 
Jika dilihat dari aspek sosial, produk dana talangan haji menyebabkan berbondong-bondongnya masyarakat untuk mendaftarkan diri guna mendapatkan kursi haji meskipun sebenarnya mereka belum sanggup membayarnya. Hal ini menyebabkan peserta tunggu semakin panjang, sehingga banyak peserta yang sebenarnya mampu namun didahului antriannya oleh mereka yang menggunakan jasa dana talangan haji dan antrian semakin panjang hingga 20 tahun. Dana talangan haji juga dipandang tidak sesuai dengan prinsip ibadah haji yaitu dilaksanakan bagi yang mampu. ${ }^{30}$ Dalam hadis riwayat alBukhārī dan Muslim, Rasulullah Saw mengingatkan; "Wahai umat manusia, hendaknya kalian mengerjakan amalan yang kuasa kalian kerjakan, karena sejatinya Allah tidak pernah merasa bosan (diibadahi) walaupun kalian sudah merasakannya. Sesungguhnya amalan yang paling dicintai Allah ialah amalan yang dilakukan secara terus menerus, walaupun hanya sedikit (HR. al-Bukhārī dan Muslim)". ${ }^{31}$

Dengan kata lain, ibadah haji dengan cara berhutang atau dengan meminjam dana talangan haji melalui perbankan masih perlu ditinjau ulang. Sebab, dalam hadis yang lain, Nabi SAW ditanya oleh 'Abd Allah bin Abì Aufā bahwa ketika ia bertanya kepada kepada Nabi SAW, berkenaan seorang lelaki yang belum naik haji, apakah ia boleh meminjam uang untuk haji ?, Nabi SAW., menjawab : “ Tidak". ${ }^{32}$ Dalam konteks ini Imam Shāfi'ī berkata, "Barangsiapa yang tidak mendapatkan kemudahan dan kelebihan harta yang menjadikanya dapat menunaikan ibadah haji tanpa melakukan pinjaman, maka ketika itu dia dianggap tidak layak untuk pergi haji. ${ }^{33}$ Uraian di atas sejalan

${ }^{30}$ yakni dilaksanakan bagi mereka yang mampu sebagaimana makna surah Ali imrān

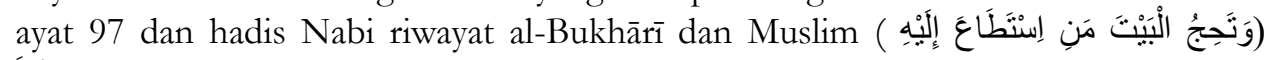
سََِيْْنِLihat Abū 'Abd Allāh bin Ismā'īl al-Bukhārī, Op.Cit, h. 27; Abū al-Husain bin alHajjaj al-Qushairī al-Naisbūrī, Op.Cit, h. 39. Yang dimaksud mani istațāa ilahi sabilā pada Surah Ali 'Imrān [3]: 97 dan Hadis tersebut yaitu: (1) perbekalan, artinya adalah perbekalan makanan, minuman dan pakaian yang mencukupi semenjak kepergiannya sampai kepulangannya; (2) kendaraan, artinya kendaraan layak yang diyakininya akan memberikan keselamatan, baik dengan membeli maupun menyewa. Lihat Abū Bakar al-Dimyațī (t.t), I'anah al-Ṭälibin, juz 2 (Beirut: Dār al-Fikr), h. 281; Muḥammad Ibn alQudamah (t.t), al-Mughni, juz 4 (Beirut: Dār al-Fikr), h. 316

31 Abū 'Abd Allāh bin Ismā̄̄l al-Bukhārī, Op.Cit, 376; Abū al-Husain bin al-Hajjaj alQushairī al-Naisbūrī, Imām Muslim, Op.Cit, h. 188.

32 Muḥammad bin Idris al-Shāfi'̄ (t.t), Op.Cit, h. 109.

${ }_{33}$ Muḥammad bin Idris al-Shāfi'ī (t.t), Op.Cit, h. 116 
dengan kaedah ușūl fiqh yang menyatakan bahwa "Menolak Mafsadah (kerusakan/ bahaya) dan menolak bahaya lainnya didahulukan daripada mengambil manfaat". ${ }^{34}$ Oleh karena itu, jika dalam transaksi pembiayaan dana talangan haji memungkinkan terbuka nya pintu bahaya atau kerusakan, misal timbulnya unsur riba, maka transaksi pembiayaan dana talangan haji tersebut harus segera ditinggalkan.

\section{Simpulan}

Penyaluran dana talangan haji pada Bank Mega Syariah Cabang Pekanbaru menggunakan prinsip Qard wa al-Ijärah, penetapan upah jasa (fee/ujrah) dan penetapan pembayaran. Penyaluran dana talangan haji yang dijalankan Bank Mega Syariah Cabang Pekanbaru dalam aplikasinya, pihak bank mengmbil imbalan atau upah dengan jumlah yang sama, dan nasabah hanya membayar upah jasa sesuai dengan jumlah yang telah ditetapkan oleh bank dan sesuai dengan kesepakatan pada saat akad dana talangan haji. Tindakan ini dilakukan untuk memberikan kemudahan. Adapun manfaat lebih yang diberikan bank kepada nasabah dengan peluncuran program dana talangan haji Bank Mega Syariah Cabang Pekanbaru, antaranya; (1) nasabah dijamin bisa mendapatkan kursi haji dengan cepat, meskipun dari dana mereka tidak tidak mencukupi pembayaran biaya perjalanan haji, sehingga dapat daftar sebagai calon jamaah haji pada Kementerian Agama; (2) mencairkan dana secara mendesak bagi nasabah yang dananya masih belum bisa dicairkan dalam waktu cepat meskipun masih dalam bentuk deposito; (3) proses pemberian dana talangan haji relative cepat, sehingga keberangkatan ibadah haji dapat terencana dan tidak menunggu lama; (4) fee atau ujrah (uang administrasi) yang diberikan relative murah; (5) nasabah hanya membayar produk dari pinjaman, bukan hanya kemudahan ini yang diberikan Bank Mega Syariah Cabang Pekanbaru; (6) nasabah dapat mengansur setiap bulan atau bisa juga dibayar langsung atau sekaligus sampai akhir pembayaran. ${ }^{35}$ Namun demikian, di sisi negatif dari pembiayaan dana talangan haji Bank Mega Syariah Cabang Pekanbaru, ia bisa saja dianggap sebagai bagian dari fath al-dzari'ab (membuka pintu bahaya) dan mendatangkan bahaya (mafsadab/ mudarat). Ditinjau dari

${ }^{34}$ Imām Jalal al-Dīn bin 'Abd al-Rahmān al-Suyūṭi (t.t), al-Aṣbāh wa al-Nazäir, Juz 1 (Beirut: Dār Fikr), h. 161

35 Ana Handayani, Widodo dan Maulana, RO Haji/PDTH, Wawancara, Bank Mega Syariah Cabang Pekanbaru, Tanggal 15 Desember 2012. 
Hukum Islam, keabsahan akadnya yang sangat riskan menjatuhkan kepada riba tersembunyi, karena dalam akad ini terjadi penggabungan antara akad al-qard dan al-ijärah dengan mensyaratkan adanya tambahan imbalan sebagai jasa, bahkan tambahan tersebut besarnya tergantung pada jumlah pinjaman dan lamanya masa pinjaman. Dalam fiqh muamalah dikenal kaedah bahwa "Setiap piutang yang mendatangkan keuntungan atau lebih adalah riba"36

\section{Daftar Pustaka}

Al-Anșārī Abū Yaḥyā Zakariyyā (t.t). Fatḥ al-Wabāb bi Sharh Manhāj al-Tullāb. Juz 1. Beirut : Dār al-Fikr.

Al-Bukhārī, Abū 'Abd Allāh bin Ismā'īl. Șahịh al-Bukhārì. Juz 1. Semarang: Maktabah Toha Putra, 2003.

Al-Dimyațī, Abū Bakar (t.t). I'anah al-Tăalibìn. juz 2. Beirut: Dār al-Fikr.

Dokumentasi, Bank Mega Syariah Cabang Pekanbaru, 08 Maret 2012.

Ibn Ḥanbal, Imām Abū 'Abd Allāh (t.t). Musnad Imām Ahmad. Juz 2. Beirut: Dār al-Fikr.

Ibn Qudāmah, Muḥammad (t.t). al-Mughnì. Juz 4. Beirut: Dār al-Fikr.

Ibn Taimiyah Taqiyuddin 'Abd al-Abbas Aḥmad bin 'Abd al-Salām bin 'Abd Allāh bin Muḥammad bin (t.t). al-Majmū' al-Fatāwā. Juz 29. Kairo: Maktabah Dār al-Salām.

Jazuni. Legislasi Hukum Islam Di Indonesia. Jakarta :Citra Aditya Bhakti, 2005.

Al-Jazairi, 'Abd al-Raḥmān. al-Fiqh 'Alā Mazahib al-Arba'ah. Juz 4. Meșir, Maktabah al-Tijāriyah, 1999.

Majelis Ulama Indonesia. Fatwa DSN-MUI No. 9/DSN-MUI/IV/2000. Jakarta: MUI, 2000

Al-Naisbūrī, Abū al-Husain bin al-Ḥajjaj al-Qushairī, Imām Muslim. Sahīh Muslim. Juz 1. Beirut: Dār al-Fikr, 1992.

Al-Nawāwī, Muḥammad bin 'Umar al-Jāwī. Nihāyah al-Zain fì Ishad al-Mutāilibin. Semarang: Toha Putra, 2000).

Ramlī, Imām, Nihāyaàt al-Muhtāj. Juz 4. Semarang: Toha Putra, 2000. Al-Rashīd, Sulaimān. Fiqh Islām. Jakarta: Pelajar, 2009.

\footnotetext{
36 Abū Isḥāq Ibrāhim al-Shirāzī (t.t), al-Muhadzdzab,Juz 1 (Beirut : Dār al-Fikr), h. 304. Taqiyuddin Abd al-Abbas Ahmad bin 'Abd al-Salām bin 'Abd Allāh bin Muḥammad bin Taimiyah (t.t), al-Majmū' al-Fatāwā, Juz 29 (Kairo: Maktabah Dār al-Salām), h. 533. Abū Yaḥyā Zakariyyā al-Anșārī (t.t), Fatḥ al-Wahāb bi Sharh Manhāj al-Tullāb, Juz 1 (Beirut : Dār al-Fikr), h. 327.
} 
Rosyada, Dede. Hukum Islam Dan Pranata Sosial. Jakarta : PT. Raja Grafindo Persada, 1999.

Sābiq, Sayyīd. Fiqh al-sunnah. Juz 8. Kairo : Maktabah Dār al-salām, 1998.

Al-Shāfi'î, Muḥammad bin Idris. al-Umm. Juz 2. Beirut : Dār al-Fikr. (t.t). Musnad al-Shäfì̃. Juz 1. Beirut: Dār al-Fikr

Al-Sharbīnī, Imām Khāṭib. Mughnì al-Mubtāj. Juz 2. Semarang: Toha Putra, 2000.

Al-Shirāzī, Abū Isḥāq Ibrāhim (t.t). al-Muhadð̨đz̧ab. Juz 1. Beirut : Dār al-Fikr Al-Sijistānī, Abū Dāwūd Sulaimān bin al-Asy'ats. Sunan Abū Dāwūid. Juz 1. Beirut: Dār al-Fikr, 1990

Al-Suyūṭị, Imām Jalal al-Dīn bin 'Abd al-Rahmān (t.t). al-Aṣbāh wa al-Nazäir. Juz 1. Beirut: Dār Fikr

Al-Turmudhī, Abū Isā Muḥammad bin Isā. Sunan al-Turmudhì. Juz 1. Beirut: Dār al-Fikr, 1980.

\section{Interview:}

Ana Handayani, Widodo dan Maulana, RO Haji/ PDTH, Wawancara, Bank Muamalat Indonesia Cawangan Pekanbaru, 20 Agustus 2014.

Laode Lukman Hasimin (Kepala Cabang) dan Pitria Liza (Kepala Operasional), Wawancara, Bank Mega Syariah Cabang Pekanbaru

Jufri dan Nur'aini, Nasabah Bank Mega Syariah Cabang Pekanbaru, Wawancara, Pekanbaru, 23 Desember 2012

Lukman dan Siti Zahara, Nasabah Bank Mega Syariah Cabang Pekanbaru, Wawancara, Pekanbaru, 23 Desember 2012

Abdullah dan Rafi'ah, Nasabah Bank Mega Syariah Cabang Pekanbaru, Wawancara, Pekanbaru, 23 Desember 2012

Mannan dan Khairiyah, Nasabah Bank Mega Syariah Cabang Pekanbaru, Wawancara, Pekanbaru, 23 Desember 2012

Muhammad Irfan dan Nafsiah, Nasabah Bank Mega Syariah Cabang Pekanbaru, Wawancara, Pekanbaru, 23 Desember 2012

Jamhir dan Salimah, Nasabah Bank Mega Syariah Cabang Pekanbaru, Wawancara, Pekanbaru, 23 Desember 2012 
